\title{
KAJIAN KEPUASAN PEMUSTAKA TERHADAP PERANAN DESAIN INTERIOR PERPUSTAKAAN UNIVERSITAS POTENSI UTAMA
}

\author{
Siti Indah Lestari \\ Prodi Desain Interior \\ Fakultas Seni dan Desain Universitas Potensi Utama Medan \\ indah.ayangjelek@gmail.com
}

\begin{abstract}
ABSTRAK
Perpustakaan adalah fasilitas atau tempat yang menyediakan sarana bahan bacaan. Tujuan dari perpustakaan sendiri, khususnya perpustakaan perguruan tinggi adalah memberikan layanan informasi untuk kegiatan belajar, penelitian, dan pengabdian masyarakat. Desain interior dalam perpustakaan sangat berperan dalam memberikan kenyamanan bagi pemustaka. Desain interior meliputi tata ruangan, tata pencahayaan, tata warna, tata suara dan sirkulasi udara. Perpustakaan yang baik dapat memberikan kepuasan serta kenyamanan terhadap pemustaka, oleh sebab itu kondisi fisik perpustakaan harus dalam keadaan baik, dari segi fasilitasnya maupun dari segi pelayanannya. Berdasarkan hal tersebut perlu adanya penelitian tentang kepuasan para pemustaka terhadap fasilitas perpustakaan. Dalam kajian ini penulis lebih memfokuskan tentang kepuasan pemustaka terhadap desain interior pada perpustakaan Universitas Potensi Utama. Dalam kajian ini penulis menggunakan metode deskriptif dengan menyebarkan angket/kuesioner kepada pemustaka yang sering datang ke perpustakaan sebnyak 100 orang. Berdasarkan hasil analisis data yang dikumpulkan maka di dapat hasil tingkat kepuasan pemustaka terhadap desain interior pada perpustakaan Universitas Potensi Utama sebesar 65,23\%, berdasarkan penafsiranya tingkat kepuasan pemustaka sebesar 65,23\% tersebut berada dalam kategori “Kurang Memuaskan”.
\end{abstract}

Kata kunci: Desain, Interior, Kepuasan, Pemustaka.

\begin{abstract}
The library is a facility or place that provides reading material facilities. The purpose of the library itself, the special library of universities provides information services for learning activities, research, and community service. The interior design in the library is very interesting in providing comfort for the visitors. Interior design adds spatial, lighting, color, sound and air circulation. Libraries that can provide satisfaction and comfort to visitors, therefore the physical condition of the library must be in good condition, in terms of facilities and in terms of service. Based on this, there is a need for research on the satisfaction of the users of library facilities. In this study the author focused more on the satisfaction of users of interior design at the University library of Main Potential. In this study the authors used descriptive methods by using questionnaires / questionnaires for visitors who often came to the library as many as 100 people. Based on the results of the analysis of the data collected, it can be obtained the level of satisfaction of the users of interior design in the library of the Main Potential University of $65.23 \%$, based on the interpretation of the satisfaction level of users of $65.23 \%$ according to the "Less Satisfactory" category.
\end{abstract}

Keywords: Design, interior, library, Satisfaction. 


\section{PENDAHULUAN}

Perpustakaan adalah salah satu sarana penunjang kegiatan pembelajaran mahasiswa dalam suatu institusi perguruan tinggi. Perpustakaan juga harus dapat memberikan kenyamanan serta pelayanan yang baik terhadap pemustaka, agar dapat menarik minat para pemustaka untuk datang ke perpustakkan. Dengan tidak adanya pemustaka, sebuah perpustakaan tidak akan hidup karena yang akan menjalankan aktivitas selain pustakawan adalah pemustaka (Mirfayana, 2015). Dalam hal ini, ruang baca perpustakaan yang nyaman dapat memberi kepuasan terhadap para pemustaka yang berkunjung. Pemustaka adalah usur utama sebagai pengguna secara langsung dan dapat memberikan penilaian langsung terhadap fasilitas yang ada di perpustakaan. Perpustakaan haruslah selalu memperhatikan kepuasan pemustaka terhadap fasilitas yang diberikan, seperti tata letak perabot, penataan ruang, suasana ruang baca, baik itu suhu udara, suara/bunyi, pencahayaan, dan warna. Sehingga membuat pengunjung merasa betah dalam melalukan aktivitasnya.

Berdasarkan Standar Nasional Indonesia (SNI), perpustakaan harus menyediakan ruang sekurang-kurangnya $0,5 \mathrm{~m}^{2}$ untuk setiap mahasiswa, dengan penggunaan untuk area koleksi seluas $45 \%$ yang terdiri dari ruang koleksi buku, ruang multimedia, ruang koleksi majalah ilmiah. Sementara itu, ruang pengguna seluas $30 \%$ yang terdiri dari ruang baca dengan meja baca, meja baca berpenyekat, ruang baca khusus, ruang diskusi, lemari katalog/komputer, meja sirkulasi, tempat penitipan tas dan toilet (Perpustakaan Nasional RI, 2011).

Menurut Undang-Undang RI Nomor 43 Tahun 2007 bab II pasal 6 ayat 1 Tentang Perpustakaan yang menyatakan bahwa: masyarakat berkewajiban untuk menjaga ketertiban, keamanan, dan kenyamanan lingkungan perpustakaan (Menteri Hukum dan Hak Asasi Manusia RI, 2007).

Kusumawati (2011) melakukan penelitian di Kantor Arsip dan Perpustakaan Kabupaten Klaten mengenai perancangan ulang meja dan kursi baca, hasil penelitiannya menyatakan keadaan meja dan kursi baca yang berukuran sangat sempit sehingga berpengaruh pada kesehatan pemustaka yang salah dalam posisi duduknya, setelah dilakukan perancangan ulang maka rancangan meja dan kursi baca sudah dapat mengakomodasi kebutuhan dan lebih meningkatkan kepuasan pemustaka.

Yudiansah (2013) juga meneliti pada ruang baca Perpustakaan Universitas Negeri Semarang, hasil penelitiannya banyak menemukan ketidakpuasan yang disebabkan oleh sirkulasi udara. Yang menjadi sorotan, adalah bahwa banyak pemustaka yang merasa kurang nyaman terhadap sirkulasi udara yang tidak bagus serta pendingin udara kurang mampu memberikan kesejukan dalam perpustakaan.

Berdasarkan uraian di atas dapat dilihat bahwa keberadaan seluruh fasilitas dan penataan ruang baca sangat berpengaruh terhadap kepuasan pemustaka dalam melakukan aktivitasnyan didalam perpustakaan.

Permasalahan yang timbul dari beberapa uraian diatas yaitu apakah para pemustaka juga merasa puas dengan peran perpustakaan sebagai salah satu sarana pendukung dalam proses pembelajaran di Universitas Potensi Utama. Selanjutnya pertanyaan yang diajukan dalam kajian ini, yaitu: bagaimana kepuasan pemustaka terhadap peranan desain interior pada perpustakaan Universitas Potensi Utama, yang meliputi beberapa aspek seperti tata ruangan, tata warna, pencahayaan, sirkulasi udara dan suara/bunyi. Tujuannya untuk mengetahui tingkat kepuasan pemustaka terhadap fasilitas perpustakaan yang kemudian dapat dijadikan sebagai bahan pertimbangan untuk pengembangan kedepannya pada perpustakaan. 
Penelitian dalam kajian ini menggunakan jenis penelitian deskriptif. Menurut Sugiyono (2006) metode deskriptif adalah metode yang digunakan untuk menganalisa data dengan cara memaparkan atau menggambarkan data yang telah terkumpul sebagaimana adanya tanpa membuat kesimpulan yang berlaku untuk umum.

Penelitian deskriptif merupakan jenis penelitian yang selalu menggunakan pertanyaan untuk memperoleh gambaran yang jelas dan terperinci akan data yang penulis peroleh dari responden, sehingga data yang diperoleh dari sekelompok sampel dapat digambarkan secara deskriptif mengenai kajian tingkat kepuasan pemustaka terhadap elemen interior di Perpustakaan Universitas Potensi Utama. Fokus dalam penelitian ini adalah:

1. Untuk mendapatkan penilaian sejauh mana desain interior berperan dalam memberikan kepuasan pada pemustaka.

2. Untuk mengetahui variable yang berperan dominan dalam memberikan kepuaan dan variabel yang paling buruk dalam memberikan kepuasan terhadap pemustaka.

Desain interior pada perpustakaan mempunyai peranan yang sangat penting dalam memberikan suasana kenyamanan serta kepuasan pemustaka. Pemilihan perabotan dan tata warna yang tepat serta didukung dengan pencahayaan dan sirkulasi udara yang baik akan mempengaruhi minat membaca pemustaka. Kepuasan akan didapat jika unsur-unsur desain interior saling mendukung untuk menciptakan suasana kenyamanan dalam ruangan perpustakaan.

\section{STUDI LITERATUR}

Kepuasan merupakan ungkapan atau harapan yang dingin dirasakan oleh setiap orang terhadap suatu bentuk layanan ataupun fasilitas yang diberikan suatu instansi. Sedangkan pemustaka adalah pengunjung atau orang yang menggunakan dan memanfaatkan fasilitas perpustakaan atau orang yang menggunakan suatu barang yang berkaitan dengan perpustakaan (Mirfayana, 2015).

Kepuasan pemustaka dapat diartikan sebagai suatu keadaan dalam diri seseorang atau sekelompok orang yang berkunjung ke perpustakaan dan mendapatkan sesuatu yang dibutuhkan ataupun yang diinginkan (Mirfayana, 2015). Kepuasan pemustaka dapat terpenuhi melalui ketersediaan informasi, kenyamanan yang sesuai dengan harapan dan penyediaan jasa yang baik. Untuk mewujudkan kepuasan pemustaka diperlukan perhatian khusus dan keseriusan dalam melakukannya.

Kepuasan pemustaka adalah tingkat perasaan bahagia seseorang yang berkunjung ke perpustakaan setelah membandingkan hasil yang dirasakan dengan harapanya (Lasa, 2009). Kepuasan pemustaka dapat dipengaruhi oleh kualitas koleksi, waktu layanan, kinerja layanan, respon terhadap keinginan pemustaka, pengaksesan; mudah, murah, cepat dan tepat, ketersediaan alat dan kompetensi petugas.

Kebutuhan yang diperlukan adalah rasa nyaman saat berada dalam perpustakaan, maka perpustakan yang berperan sebagai penyedia jasa informasi harus memperhatikan rasa kepuasan pemustaka terhadap pelayanan dan fasilitas perpustakaan. Menurut Cohen (1994) terdapat beberapa unsur atau elemen yang mempengaruhi desain interior suatu gedung yaitu ruang, pencahayaan, warna, sirkulasi udara dan suara.

Ching (1996) menyatakan kebutuhan luas ruang dibedakan dalam tiga jenis yaitu: kebutuhan luas ruang terhadap aktifitas yang dilakukan, perlengkapan yang dibutuhkan, dan 
banyaknya orang yang dilayani. Pemilihan jenis dan bentuk perabot yang tepat juga sangat mempengaruhi kepuasan serta kenyamanan pemustaka.

Dikarenakan warna pada dinding, lantai, atap dan perabot dapat menciptakan suasana hati dan kenyamanan seseorang, maka pemilihan warna yang tepat dapat mempengaruhi kepuasan seorang pemustaka (Pamudji, 2003).

Menurut Ching (1996) fungsi dari pencahayaan adalah menyinari bangun dan ruang dalam lingkungan interior, dan memungkinkan pemakai ruang tersebut melakukan aktifitas dan menjalankan tugasnya dengan kecepatan, akurasi, dan kenyamanan. Pencahayaan dapat berupa cahaya alami dari matahari pada siang hari dan cahaya buatan dari lampu pada siang atau malam hari.

Dengan menggunakan sistem penyejuk udara, kemurnian udara dan cara menghilangkan bau dapat dikendalikan (Ching, 1996). Menurut Basuki (1993) perpustakaan yang sejuk berkat ventilasi yang baik dan terang akan lebih berpeluang untuk menarik perhatian pengunjung atau pemustaka untuk datang dan berlama-lama dalam perpustakaan.

Tata suara juga berpengaruh dalam hal kenyamanan pemustaka, baik gangguan suara dari luar ruangan maupun suara dari dalam ruangan. Menurut Mirfayana (2015) untuk mendesain sebuah ruang perpustakaan perlu diperhatikan adanya sumber-sumber suara/bunyi yang dapat menentukan tingkat gangguan bagi pemustaka, yaitu: lama suara, frekuensi, dan intensitas suara.

Pada ruang baca perpustakaan, rak buku umumnya diletakkan ditengah ruangan secara berseblahan maupun saling membelakangi agar rak buku dapat berdiri stabil. Selain itu, dalam sebuah perpustakaan tinggi standar rak buku yang mudah dijangkau yaitu sekitar 168 $\mathrm{cm}$ (Trisiella, 2012)

Dalam perpustakaan tempat duduk dan meja harus di susun rapi dan tidak terlalu berdekatan, agar tidak terjadi persinggungan antara sesama pemustaka. Pemilihan bentuk kursi juga harus menjadi perhatian agar dapat memberikan sikap duduk yang baik, yang tidak mengakibatkan punggung menjadi sakit kaerena terlalu lama duduk. Dengan demikian, karena ukuran badan manusia sangat bervariasi maka penggunaan kursi jyang ada dalam perpustakaan haruslah juga bervariasi ukurannya. Faktor kenyamanan juga dipengaruhi oleh sifat aktivitas yang dijalani pemakai pada saat itu (Ching, 1996).

Agar data yang diperoleh lebih akurat maka penulis menggunakan metode angket/kuesioner, yakni beberapa pertanyaan/pernyataan tertulis yang akan dijawab atau dilengkapi oleh pemustaka. Jika diliihat dari bentuknya maka angket ini dibagi menjadi dua yaitu angket terbuka dan angket tertutup. Jenis angket yang digunakan adalah angket tertutup, angket tertutup yaitu responden tidak bisa memberikan jawaban lain, selain jawaban yang sudah disediakan dalam lembaran angket tersebut. Sedangkan angket terbuka, responden bebas memberikan jawaban yang sesuai dengan fikirannya.

Selain data yang diperoleh dari angket yang disebar kepada pemustaka, penulis juga menggunakan data yang berupa catatan, buku, majalah, notulen rapat, agenda yang tertulis, tercetak, atau terekam. Dalam pengumpulan data terkait dengan masalah yang akan dibahas, penulis mengadakan penelusuran dokumen-dokumen.

Alat yang digunakan dalam penelitian ini adalah lembar angket atau kuesioner yang di sebarkan kepada pemustaka, yaitu sejumlah pertanyaan tertulis dilengkapi dengan pilihan jawaban yang digunakan untuk memperoleh informasi dari responden. Menurut Sugiyono 
(2013) Jawaban setiap item instrument yang menggunakan skala Likert mempunyai gradasi dari sangat positif sampai sangat negatif yang dapat berupa kata-kata antara lain:

1. "Sangat setuju" dengan skor 5

2. "Setuju" dengan skor 4

3. "Kurang Setuju" dengan skor 3

4. "Tidak setuju" dengan skor 2

5. "Sangat tidak setuju" dengan skor 1

Analisis data yang digunakan adalah analisis data kuantitatif dengan menggunakan metode deskriptif yaitu metode yang berfungsi untuk memberikan gambaran atau deskripsi terhadap objek yang diteliti melalui data sampel atau populasi sebagaimana adanaya tanpa melakukan analisis dan membuat kesimpulan yang berlaku untuk umum (Sudjana, 2004). Adapun rumus yang digunakan adalah sebagai berikut:

$$
P=\frac{F}{N} \times 100 \%
$$

Keterangan:

$\mathrm{P}=$ frekuensi yang sedang dicari presentase

$\mathrm{N}=$ jumlah frekuensi atau jumlah responden

$\mathrm{F}=$ angka presentase (Sudjana, 2004).

Selanjutnya hasil skor $(\mathrm{P})$ ditentukan kategori penafsirannya sebagai berikut:

1. $85-100=$ sangat memuaskan

2. $70-85=$ memuaskan

3. $50-70=$ kurang memuaskan

4. $25-50=$ tidak memuaskan

5. $0-25$ = sangat tidak memuaskan

Setelah didapatkan persentase dari masing-masing pertanyaan, baru kemudian dijumlahkan setiap skor masing-masing yang didapat dari tiap pertanyaan untuk mendapatkan interval tingkat kepuasan pemustaka.

\section{PEMBAHASAN}

1. Pengumpulan Data

Pertanyaan yang akan diajukan lebih menitikberatkan kepada pengaruh desain interior terhadap kepuasan pemustaka. Pertanyaan yang diajukan ditujukan kepada para responden pemustaka yang sering berkunjung keperpustakaan. Pertanyaan yang diajukan dibuat dalam sebuah angket yang dilengkapi dengan data diri pemustaka, tabel pertanyaan yang diajukan lengkap dengan keterangan nya. Pemustaka hanya dapat meberikan pndapat setuju atau tidak setuju agar tidak terlalu banyak variasi jawaban. Agar data yang didapatkan lebih akurat diberikan juga kolom saran yang dapat diisi sesuai fikiran para pemustaka masing-masing. Lembaran angket yang disebarkan kepada para pemustaka dapat dilihat pada gambar dibawah ini: 


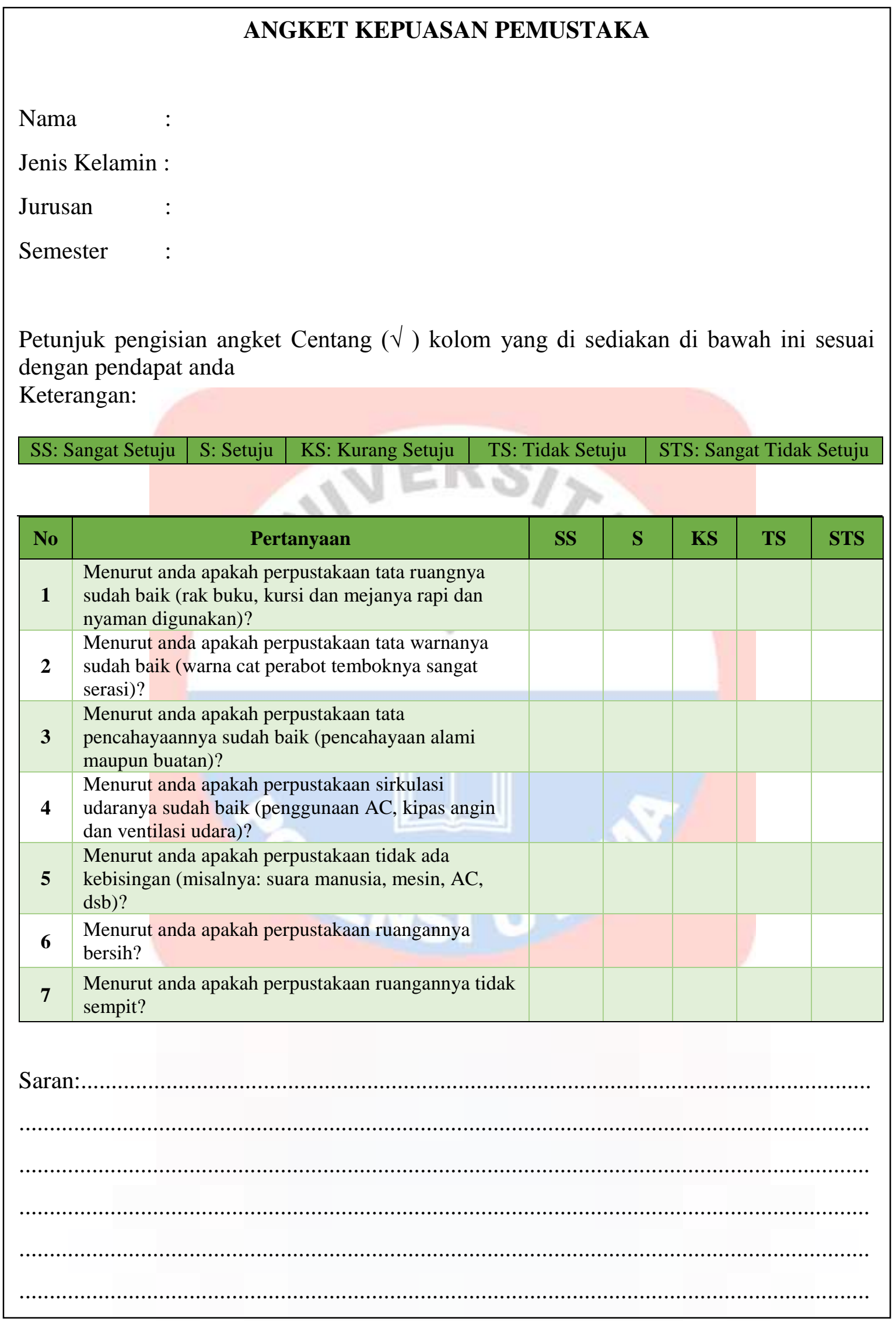

Gambar 1. Lembaran Angket Yang Di Sebarkan Kepada Pemustaka 
Dengan batuan angket tersebut maka akan lebih mudah dalam mengumpulkan data yang akurat tentang tingkat kepuasan pemustaka terhadap desain interior perpustakaan Universitas Potensi Utama. Untuk mengetahui jumlah responden maka dikelompokkan berdasarkan jenis kelamin yaitu laki-laki dan perempuan. Perbandingan jumlah responden menurut jenis kelamin didominasi oleh perempuan sebanyak 63\% sedangkan laki-laki sebanyak $37 \%$ yang dapat dilihat pada gambar berikut ini:

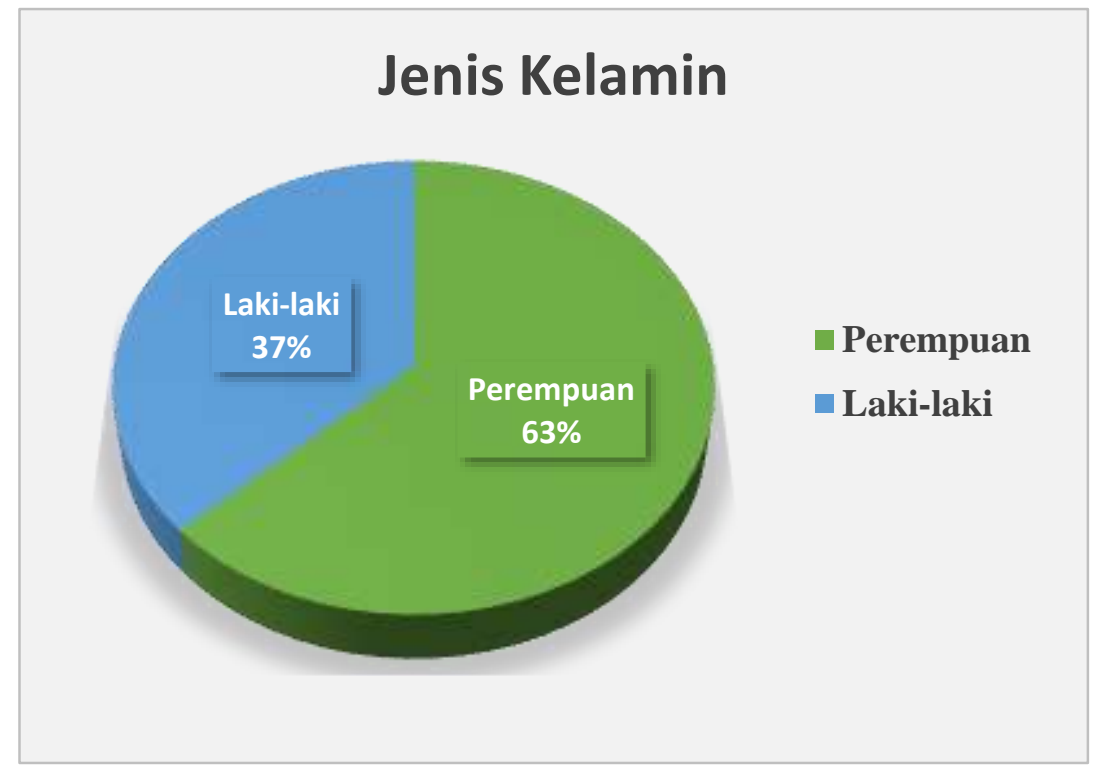

Gambar 2. Grafik Perbandingan Pemustaka Menurut Jenis Kelamin

Sedangkan jika dilihat dari tingkat semesternya data responden yang berkunjung ke perpustakaan didominasi oleh mahasiswa semester 7-8 sebanyak 40\%, sedangkan mahasiswa semester 5-6 sebanyak 30\%, mahasiswa semester 3-4 sebanyak $20 \%$ dan mahasiswa semester 1-2 sebanyak 10\%, seperti disajikan pada gambar dibawah ini:

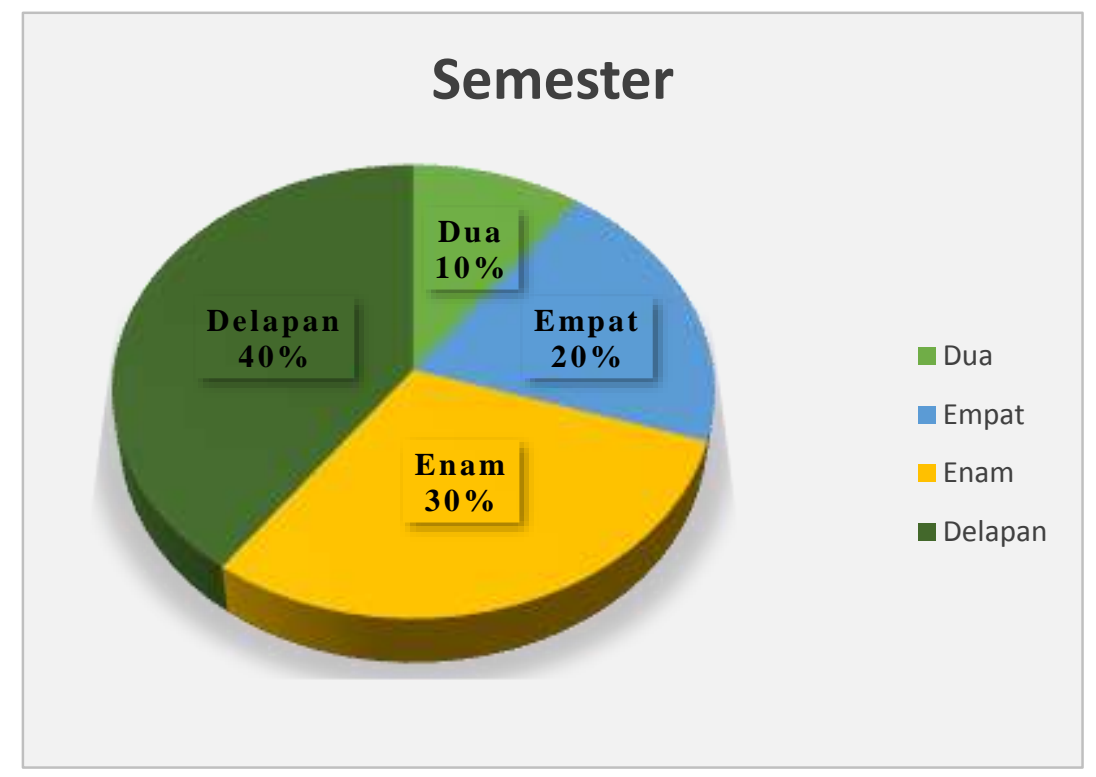

Gambar 3. Grafik Perbandingan Pemustaka Menurut Tingkat Semester 


\section{Analisis Data}

a. Menurut anda apakah perpustakaan tata ruangnya sudah baik ?

Tata ruang yang dimaksud disini mencakup penataan rak buku, penataan meda dan kursi, pemilihan model furniture, ketersediaan toilet. Berdasarkan hasil angket yang disebarkan kepada 100 orang pemustaka didapatkan persentase responden yang menjawab setuju dengan tata ruang yang sudah baik sebanyak 9 orang (9\%), sedangkan persentase terbesar nya menjawab kurang setuju yaitu 42 orang (42\%), seperti disajikan dalam tabel 1. Hal ini disebabkan karena tidak adanya sekat antara meja yang satu dengan meja yang lainnya menyebabkan pemustaka merasa terganggu dengan pemustaka yang ada disekitarnya.

Tabel 1.Pertanyaan no 1

\begin{tabular}{|c|l|c|c|c|c|}
\hline \multirow{2}{*}{ No } & \multirow{2}{*}{ Uraian } & Skor & Fekuensi & \multirow{2}{*}{ SxF } & \multirow{2}{*}{ Presentase (\%) } \\
\cline { 3 - 4 } & & $(\mathrm{S})$ & $(\mathrm{F})$ & & \\
\hline 1 & Sangat Setuju & 5 & 0 & 0 & $0.0 \%$ \\
\hline 2 & Setuju & 4 & 9 & 36 & $9.0 \%$ \\
\hline 3 & Kurang Setuju & 3 & 42 & 126 & $42.0 \%$ \\
\hline 4 & Tidak Setuju & 2 & 35 & 70 & $35.0 \%$ \\
\hline 5 & Sangat Tidak Setuju & 1 & 14 & 14 & $14.0 \%$ \\
\hline Jumlah & & 100 & 246 & $100 \%$ \\
\hline
\end{tabular}

Sumber: data diolah 2017

b. Menurut anda apakah perpustakaan tata warnanya sudah baik ?

Tata warna yang dimaksud meliputi penggunaan warna pada dinding, warna perabot, warna lantai, maupun warna plafon. Kondisi yang ada pada saat ini ruangan perpustakaan Universitas Potensi Utama di dominasi dengan perabotan warna coklat muda dan wana putih pada lantai dan plafon. Hal ini juga membuat banyaknya responden yang kurang setuju akibat warna yang membosankan pada ruangan. Hasil dari pertanyaan ini disajikan pada tabel berikut:

Tabel 2. Pertanyaan No 2

\begin{tabular}{|c|l|c|c|c|c|}
\hline \multirow{2}{*}{ No } & \multirow{2}{*}{ Uraian } & Skor & Fekuensi & \multirow{2}{*}{ SxF } & \multirow{2}{*}{ Presentase (\%) } \\
\cline { 3 - 4 } & & $(\mathrm{S})$ & $(\mathrm{F})$ & & \\
\hline 1 & Sangat Setuju & 5 & 6 & 30 & $6.0 \%$ \\
\hline 2 & Setuju & 4 & 35 & 140 & $35.0 \%$ \\
\hline 3 & Kurang Setuju & 3 & 40 & 120 & $40.0 \%$ \\
\hline 4 & Tidak Setuju & 2 & 17 & 34 & $17.0 \%$ \\
\hline 5 & Sangat Tidak Setuju & 1 & 2 & 2 & $2.0 \%$ \\
\hline Jumlah & & 100 & 326 & $100 \%$ \\
\hline
\end{tabular}

Sumber: data diolah 2017

c. Menurut anda apakah perpustakaan pencahayaan sudah baik ?

Tata pencahayaan meliputi pencahayaan alami seperti sinar matahari pada siang hari dan pencahayaan buatan seperti pemasangan lampu pada ruangan. Kodisi pada saat ini ruangan perpustakaan hanya menggunakan pencahayaan buatan seperti lampu, dikarekanan tidak adanya jendela yang menghadap langsung keluar. Hasil jawaban yang didapat dari responden disajikan dalam tabel berikut: 
Tabel 3. Pertanyaan No 3

\begin{tabular}{|c|l|c|c|c|c|}
\hline \multirow{2}{*}{ No } & \multirow{2}{*}{ Uraian } & Skor & Fekuensi & \multirow{2}{*}{ SxF } & \multirow{2}{*}{ Presentase (\%) } \\
\cline { 3 - 4 } & & $(\mathrm{S})$ & $(\mathrm{F})$ & & \\
\hline 1 & Sangat Setuju & 5 & 30 & 150 & $30.0 \%$ \\
\hline 2 & Setuju & 4 & 35 & 140 & $35.0 \%$ \\
\hline 3 & Kurang Setuju & 3 & 6 & 18 & $6.0 \%$ \\
\hline 4 & Tidak Setuju & 2 & 17 & 34 & $17.0 \%$ \\
\hline 5 & Sangat Tidak Setuju & 1 & 12 & 12 & $12.0 \%$ \\
\hline Jumlah & & 100 & 354 & $100 \%$ \\
\hline
\end{tabular}

Sumber: data diolah 2017

d. Menurut anda apakah perpustakaan sirkulasi udaranya sudah baik ?

Sirkulasi udara yang baik pada suatu ruangan sagat perlu demi kenyamanan pemustaka, karena jika udara tidak bersirkulasi dengan baik maka udara ruangan akan pengap dan kualitas udara dalam ruagan juga kurang baik. Penggunaan AC dan exhaust pada ruangan perpustakaan juga sangat membantu agar sirkulasi udara dalam ruangan terus berputar serta memberikan kesejukan pada pemustaka. Hasil jawaban yang didapat dari responden disajikan dalam tabel berikut:

Tabel 4. Pertanyaan no 4

\begin{tabular}{|c|l|c|c|c|c|}
\hline \multirow{2}{*}{ No } & \multirow{2}{*}{ Uraian } & Skor & Fekuensi & \multirow{2}{*}{ SxF } & \multirow{2}{*}{ Presentase (\%) } \\
\cline { 3 - 4 } & & $(\mathrm{S})$ & $(\mathrm{F})$ & & \\
\hline 1 & Sangat Setuju & 5 & 7 & 35 & $7.0 \%$ \\
\hline 2 & Setuju & 4 & 25 & 100 & $25.0 \%$ \\
\hline 3 & Kurang Setuju & 3 & 38 & 114 & $38.0 \%$ \\
\hline 4 & Tidak Setuju & 2 & 18 & 36 & $18.0 \%$ \\
\hline 5 & Sangat Tidak Setuju & 1 & 12 & 12 & $12.0 \%$ \\
\hline Jumlah & & 100 & 297 & $100 \%$ \\
\hline
\end{tabular}

Sumber: data diolah 2017

e. Menurut anda apakah perpustakaan tidak ada kebisingan ?

Kebisingan adalah faktor yang sangat mengganggu para pemustaka saat dalam perpustakaan, sumber kebisingan bisa berupa suara pemustaka lainnya yang mengobrol, suara kipas angin, suara AC dan suara yang berasal dari luar ruangan. Hasil jawaban yang didapat dari responden disajikan dalam tabel berikut:

Tabel 5. Pertanyaan no 5

\begin{tabular}{|c|l|c|c|c|c|}
\hline \multirow{2}{*}{ No } & \multirow{2}{*}{ Uraian } & Skor & Fekuensi & \multirow{2}{*}{ SxF } & \multirow{2}{*}{ Presentase (\%) } \\
\cline { 3 - 4 } & & $(\mathrm{S})$ & $(\mathrm{F})$ & & \\
\hline 1 & Sangat Setuju & 5 & 42 & 210 & $42.0 \%$ \\
\hline 2 & Setuju & 4 & 35 & 140 & $35.0 \%$ \\
\hline 3 & Kurang Setuju & 3 & 6 & 18 & $6.0 \%$ \\
\hline 4 & Tidak Setuju & 2 & 9 & 18 & $9.0 \%$ \\
\hline 5 & Sangat Tidak Setuju & 1 & 8 & 8 & $8.0 \%$ \\
\hline Jumlah & & 100 & 394 & $100 \%$ \\
\hline
\end{tabular}

Sumber: data diolah 2017 
f. Menurut anda apakah perpustakaan ruangannya bersih?

Ruangan perpustakaan memang haruslah dijaga kebersihannya baik itu oleh petugas kebersihan perpustakaan maupun para pemustaka itu sendiri. Saat berada didalam perpustakaan hendaklah untuk tidak melakukan aktivitas makan. Hasil jawaban yang didapat dari responden disajikan dalam tabel berikut:

Tabel 6. Pertanyaan no 6

\begin{tabular}{|c|l|c|c|c|c|}
\hline \multirow{2}{*}{ No } & \multicolumn{1}{|c|}{ Uraian } & Skor & Fekuensi & \multirow{2}{*}{ SxF } & \multirow{2}{*}{ Presentase (\%) } \\
\cline { 3 - 4 } & & $(\mathrm{S})$ & $(\mathrm{F})$ & & \\
\hline 1 & Sangat Setuju & 5 & 69 & 345 & $69.0 \%$ \\
\hline 2 & Setuju & 4 & 19 & 76 & $19.0 \%$ \\
\hline 3 & Kurang Setuju & 3 & 6 & 18 & $6.0 \%$ \\
\hline 4 & Tidak Setuju & 2 & 6 & 12 & $6.0 \%$ \\
\hline 5 & Sangat Tidak Setuju & 1 & 0 & 0 & $0.0 \%$ \\
\hline Jumlah & & 100 & 451 & $100 \%$ \\
\hline
\end{tabular}

Sumber: data diolah 2017

g. Menurut anda apakah perpustakaan ruangannya tidak sempit?

Ruangan dalam perpustakaan sebaiknya tidak terlalu sempit, agar parapemustaka tidak saling terganggu saat melakukan aktivitas dalam perpustakaan. Hasil jawaban yang didapat dari responden disajikan dalam tabel berikut:

Tabel 7. Pertanyaan no 7

\begin{tabular}{|c|l|c|c|c|c|}
\hline \multirow{2}{*}{ No } & \multirow{2}{*}{ Uraian } & Skor & Fekuensi & \multirow{2}{*}{ SxF } & \multirow{2}{*}{ Presentase (\%) } \\
\cline { 3 - 4 } & & $(\mathrm{S})$ & $(\mathrm{F})$ & & \\
\hline 1 & Sangat Setuju & 5 & 0 & 0 & $0.0 \%$ \\
\hline 2 & Setuju & 4 & 6 & 24 & $6.0 \%$ \\
\hline 3 & Kurang Setuju & 3 & 26 & 78 & $26.0 \%$ \\
\hline 4 & Tidak Setuju & 2 & 45 & 90 & $45.0 \%$ \\
\hline 5 & Sangat Tidak Setuju & 1 & 23 & 23 & $23.0 \%$ \\
\hline Jumlah & & 100 & 215 & $100 \%$ \\
\hline
\end{tabular}

Sumber: data diolah 2017

Dari semua pertanyaan yang diajukan kepada pemustakan diperoleh perbedan persentase dari setiap pertanyaan yang diajukan. Pertanyaan nomor 1 tentang tata ruangan sebesar $35,14 \%$, pertanyaan nomor 2 tentang tata warna sebesar $46,57 \%$, pertanyaan nomor 3 tentang tata pencahayaan sebesar $50,57 \%$, pertanyaan nomor 4 tentang sirkulasi udara sebesar $42,43 \%$, pertanyaan nomor 5 tentang kebisingan sebesar $56,29 \%$, pertanyaan nomor 6 tentang kebersihan ruangan sebesar $64,43 \%$ dan yang terakhir tentang ukuran ruangan perpustakaan sebesar $30,71 \%$. Dapat dilihat dari semua pertanyaan yang diajukan, pada pertanyaan terakhir tentang ukuran ruangan perpustakaan medapatkan persentase yang sangat kecil dari pemustaka, sedangkan yang paling tinggi persentasenya didapat pada pertanyaan nomor 5 tentang kebersihan ruangan perpustakaan. Perbandingan tingkat kepuasan dapat dilihat pada gambar berikut ini: 


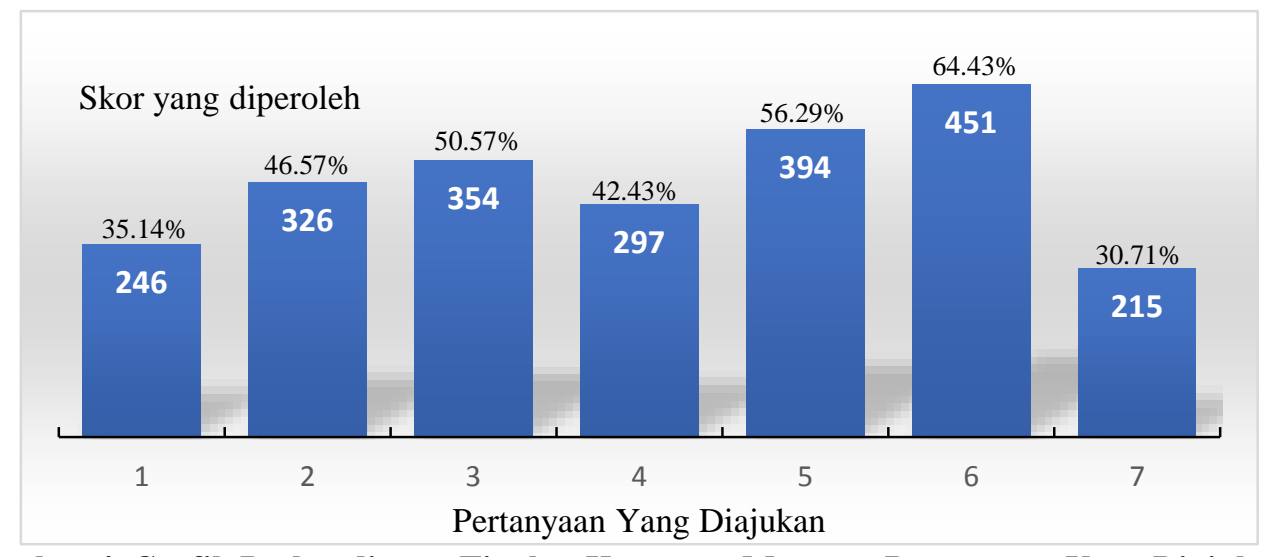

Gambar 4. Grafik Perbandingan Tingkat Kepuasan Menurut Pertanyaan Yang Diajukan

Jumlah skor kriteria (bila setiap pertanyaan mendapat skor tertinggi) $=5 \times 7 \times 100=$ 3500 point. Untuk ini skor tertinggi tiap pertanyaan $=5$, jumlah pertanyaan $=7$ dan jumlah responden $=100$. Jumlah skor hasil pengumpulan data $=2283$ point. Dengan demikian tingkat kepuasan pemustaka terhadap desain interior di Perpustakaan Universitas Potensi Utama berdasarkan tanggapan responden yaitu $2283: 3500=65,23 \%$ dari kriteria yang ditetapkan, seperti diperlihatkan pada gambar dan tabel berikut ini:

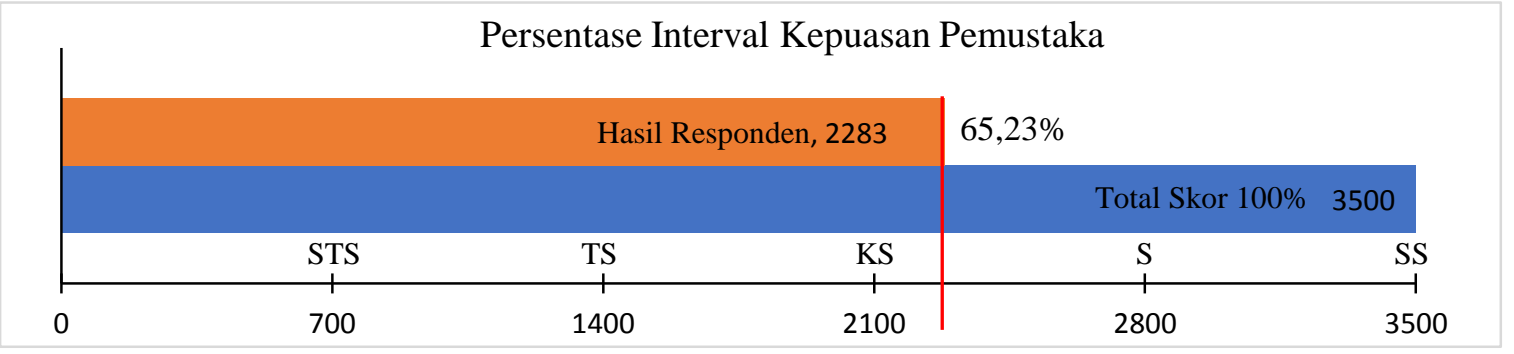

Gambar 5. Grafik Persentase Interval Kepuasan Pemustaka

Tabel 8: Rekapitulasi hasil responden .

\begin{tabular}{|c|c|c|c|c|c|c|c|c|c|c|c|c|}
\hline \multirow{2}{*}{ Jawaban } & \multirow{2}{*}{ Skor } & \multicolumn{7}{|c|}{ Pertanyaan } & \multirow{2}{*}{ Jumlah } & \multirow{2}{*}{$\%$} & \multirow{2}{*}{$\begin{array}{c}\text { Jumlah } \\
\text { x skor }\end{array}$} & \multirow{2}{*}{$\begin{array}{c}\text { Nilai } \\
\text { maksima }\end{array}$} \\
\hline & & 1 & 2 & 3 & 4 & 5 & 6 & 7 & & & & \\
\hline SS & 5 & 0 & 6 & 30 & 7 & 42 & 69 & 0 & 154 & $22.00 \%$ & 770 & 700 \\
\hline$S$ & 4 & 9 & 35 & 35 & 25 & 35 & 19 & 6 & 164 & $23.43 \%$ & 656 & 700 \\
\hline $\mathrm{KS}$ & 3 & 42 & 40 & 6 & 38 & 6 & 6 & 26 & 164 & $23.43 \%$ & 492 & 700 \\
\hline $\mathrm{TS}$ & 2 & 35 & 17 & 17 & 18 & 9 & 6 & 45 & 147 & $21.00 \%$ & 294 & 700 \\
\hline STS & 1 & 14 & 2 & 12 & 12 & 8 & 0 & 23 & 71 & $10.14 \%$ & 71 & 700 \\
\hline \multicolumn{2}{|l|}{ Jumlah } & 100 & 100 & 100 & 100 & 100 & 100 & 100 & 700 & $100 \%$ & 2283 & 3500 \\
\hline \multicolumn{11}{|c|}{ Persentase Kriteria Hasil Responden } & \multicolumn{2}{|c|}{$65.23 \%$} \\
\hline
\end{tabular}

Sumber: data diolah 2017

\section{Hasil Analisis}

Berdasarkan hasil analisis data yang dikumpulkan maka di dapat hasil tingkat kepuasan pemustaka terhadap desain interior pada perpustakaan Universitas Potensi Utama sebesar $65,23 \%$, skor tersebut berada dalam interval antara "Kurang Setuju" dan "Setuju" tetapi lebih mendekati "Kurang Setuju". Berdasarkan penafsiranya tingkat kepuasan pemustaka sebesar 65,23\% tersebut berada dalam kategori "Kurang Memuaskan". Nilai skor tersebut masi sangat kurang untuk sebuah perpustakaan perguruan tinggi karena banyak dari pertanyaan yang diajukan mendapatkan respon kurang setuju dari pemustaka. 


\section{KESIMPULAN}

Berdasarkan hasil dan pembahasan dalam kajian ini dapat disimpulkan bahwa:

1. Para pemustaka yang berkunjung ke perpustakaan di dominasi oleh pemustaka wanita dengan persentase (63\%), sedangkan pemustaka pria (37\%). Jika dilihat dari tingkat semesternya mahasiswa tingkat semester $7-8$ persentasenya paling tinggi (40\%) dari pada semester dibawah nya.

2. Dari semua pertanyaan yang diajukan kepada responden, jawaban didominasi "kurang setuju" dengan persentase yang rendah, pertanyaan nomor 1 tentang tata ruangan sebesar $35,14 \%$, pertanyaan nomor 2 tentang tata warna sebesar $46,57 \%$, pertanyaan nomor 3 tentang tata pencahayaan sebesar 50,57\%, pertanyaan nomor 4 tentang sirkulasi udara sebesar 42,43\%, pertanyaan nomor 5 tentang kebisingan sebesar 56,29\%, pertanyaan nomor 6 tentang kebersihan ruangan sebesar 64,43\% dan yang terakhir tentang ukuran ruangan perpustakaan sebesar $30,71 \%$, yang berarti para responden merasa kurang puas dengan kondisi perpustakaan yang ada sekarang.

3. Persentase tingkat kepuasan pemustaka sebesar $65,23 \%$, yang berada dalam interval kurang setuju dan setuju, namun lebih mendekati kurang setuju dan masuk dalam kategori "Kurang Memuaskan".

4. Peranan desain interior seperti penataan ruang, pemilihan warna yang tepat, pencahayaan yang baik, sirkulasi udara yang baik serta kontrol bunyi/kebisingan yang sangatlah penting dalam menciptakan suasana yang nyaman dan dapat memberikan kepuasan kepada pemustaka.

\section{DAFTAR PUSTAKA}

[1] Ching, Francis D.K. (1996). Ilustrasi Desain Interior. Jakarta: Erlangga.

[2] Suptandar, Pamudji. (2003). Perancangan Tata Ruang Dalam Desain Interior. Jakarta: PT. Djambatan.

[3] Pustakawan Universitas Gadjah Mada. 2017. Berkala Ilmu Perpustakaan dan Informasi Vol. 13 No. 1, Juni 2017 ISSN 2477-0361.

[4] Mirfayana. (2015). Analisis Tingkat Kepuasan Pemustaka Terhadap Ruang Baca Di Perpustakaan Universitas Muhammadiyah Makasar. Tugas Akhir: Universitas Muhammadiyah Makasar

[5] Sudjana, A. (2004). Pengantar Statistik Pendidikan. Jakarta: Raja Grafindo Persada.

[6] Perpustakaan Nasional RI. (2011). Standar Nasional Indonesia Bidang Perpustakaan dan Kepustakawanan. Jakarta: Perpustakaan Nasional RI.

[7] Lasa, H.S. (2005). Manajemen Perpustakaan. Cet. I; Yogyakarta: Gama Media.

[8] Menteri Hukum dan Hak Asasi Manusia RI. (2007). Undang-Undang Republik Indonesia Nomor 43 Tahun 2007 Tentang Perpustakaan. Jakarta. 
[9] Sulistyo-Basuki. (1993) Pengantar Ilmu Perpustakaan. Jakarta: Gramedia Pustaka Utama.

[10] Sugiyono. (2006). Metode Penelitian Bisnis. Bandung: Alfabeta.

[11] Sugiyono. (2013). Metode Penelitian Kuantitatif, Kualitatif, dan R \& D. Cet. 19. Bandung: Alfabeta.

[12] Yudiansah, Choeroh. (2013). Analisis Kenyamanan Ruang Perpustakaan Universitas Negeri Semarang Berdasarkan Persepsi Mahasiswa (Studi Kasus: Ruang Baca Koleksi Skripsi Perpustakaan Universitas Negeri Semarang). Skripsi. Semarang: Fakultas Teknik. http://lib.unnes.ac.id/19103/1/5101407012.pdf. (10 maret 2015).

[13] Kusumawati, Intan. (2011). Perancangan Ulang Meja dan Kursi Baca Berdasarkan Aspek Fungsi dan Kenyamanan Sesuai Kebutuhan Pengguna Perpustakaan (Studi Kasus di Kantor Arsip dan Perpustakaan Kabupaten Klaten). Skripsi. http://eprints.uns.ac.id/7107/1/191901611201109531.pdf (26 Januari 2015). 